\title{
Academic Success in 1st-year Engineering Students: Key Factors
}

\author{
Rosa M. Vasconcelos \\ $2 \mathrm{C} 2 \mathrm{~T}$ \\ Centro de Ciência e Tecnologia Têxtil \\ Minho University \\ Guimaraes, Portugal \\ rosa@det.uminho.pt
}

\author{
Leandro S. Almeida \\ Institute of Education \\ Research Center on Education \\ University of Minho \\ Braga, Portugal \\ leandro@ie.uminho.pt
}

\begin{abstract}
This work-in-progress research to practice paper analyzes how previous personal, social and academic variables converge in the explanation of students' academic performance, during the 1st year of Engineering courses. A sample of 737 1st year students of Engineering courses in a Portuguese public university was considered. Students age ranging from 16 to 41 years old $(M=18.29, S D=2.01)$, having entered the university with a GPA ranging from 154.6 to $200.0(M=154.60, S D=18.10)$. Two measures of academic achievement were taken into account in this study: the number of subjects/curricular units successfully completed at the end of the 1st semester, and the average of the marks obtained in the approved curricular units at the end of the 1st year. In terms of predictors, we considered sex, age, parents' academic education, course and university option and access GPA. The regression analysis shows that GPA and sex have a higher impact on academic achievement. These data deserve attention from institutions and professors since some students access their courses without the necessary level of academic competencies, motivation and vocational career definition which justifies the need for diagnosing and levelling students' background and personal characteristics. It is also important because several students are not in their first option institution/course, which also impacts their adjustment process to the University.
\end{abstract}

Keywords-higher education, engineering students, 1st-year students, academic success, GPA

\section{INTRODUCTION}

The transition to Higher Education is experienced by young people with a mix of excitement and anxiety facing new developments and challenges [1,2]. University represents a rich time for growth and the preparation of young people to access the labor market and enter adult life. Sometimes, students do not have the necessary level of maturity and autonomy to face the demands of the new context of academic life $[3,4]$. Institutions have implemented support services to attend the specific needs of a more diverse public. First-year undergraduate students worldwide show difficulties in adapting and achieving academic success. Several personal, social and academic variables impact negatively their adjustment and, therefore, relevant dropout rates are observed during the first year $[5,3]$. When the difficulties of adapting to university are not overcome, the risks of failure and dropout increase.

Difficulties in adapting to the new context and ambiguous feelings concerning the course are particularly felt during the first year $[3,4,6]$. For example, students might not have the necessary level of skills, motivation, learning strategies or interpersonal relationships with colleagues and teachers to face the new challenges, especially, students leaving their parents' home to study at the university. In particular, when their engineering courses appeal for scientific (physical, chemical) and mathematical areas have not been developed to a desirable extent during secondary school. In order to help this transition, some seminars are introduced in the curriculum to assist students to develop autonomy, interpersonal relationship skills and learning strategies [7]. These seminars are associated to the development of students' psychological well-being and academic success [8,2], reducing the risks of dropout, whose higher rates tend to occur precisely during their first year[9-12].

Several variables impact the adaptation to University. For example, in Engineering courses, female students are confronted with courses and classrooms predominantly attended by men which may cause social pressure due to these social stereotypes that associate the courses of Engineering as male courses. Also, their expectations, regarding academic life and the preparation of a future career or professional activity are different when compared to male students [13].

In Portugal, the access to university is nationally organized on the basis of a GPA (from 0 to 200 points; minimum of 100 points to enter public universities) taking high school classifications and national exams' grades of the courses' scientific areas. As anticipated, the system of numerus clausus does not allow all students to access their first course options. Official data from the Ministry of Education show that each year, approximately, $50 \%$ of students are not involved in their 
first option course and/or institution. In consequence, students with higher GPA, who have not been placed in their first option, take a course/institution that has been chosen as the first option by other colleagues, producing waves of discontent [14]. Surely, this specific situation will have an impact on students' adaptation, learning, achievement and permanence in higher education [5,15]. Also in Portugal, the majority of students come from families without a tradition of higher education. Families socioeconomic status is a strong predictor of students' academic achievement and permanence [16,17]. Low levels of permanence and course conclusion occur in students coming from minority groups and families with low socioeconomic resources [4,18-20].

This work-in-progress research to practice paper analyzes how previous personal, social and academic variables converge for the explanation of academic performance, during the 1st year, in Engineering courses. For assessing academic achievement in university two criteria have been considered: the number of subjects/curricular units successfully completed, at the end of the 1st semester, and the average of the marks obtained in the approved curricular units, at the end of the 1st year.

\section{METHOD}

\section{A. Sample}

A sample of 737 Portuguese first-year engineering students has been considered in this study. Most of them are male students $(67 \%)$ attending their first option course $(51.8 \%)$ and university $(69.7 \%)$. The ages are distributed between 16 as minimum and 41 years old as the maximum $(\mathrm{M}=18.29, \mathrm{SD}=$ 2.01). Considering the GPA of access to higher education, on a scale of 0 to 200 points, the minimum was 107 and the maximum was $200(\mathrm{M}=154.60$; $\mathrm{SD}=18.01) .36 .9 \%$ of these students left home to study at the University. Regarding parents' school graduation, only $26.9 \%$ of students' fathers have a higher education degree (31.8\% in case of mothers), which means that there is a large percentage of students as a first generation in higher education.

\section{B. Instrument and Procedures}

At the time of enrollment at the university, students completed a questionnaire reporting on their personal, sociofamily and secondary education academic variables. They have been asked about their access classification (GPA) and if they were attending a first option graduation course and/or University. At the end of the 1st semester, administrative services provided the number of ECTS that the students have successfully completed, as well as the average of the grades obtained at the end of the 1st year. Taking the previous personal, socio-family and academic variables as predictors, we proceeded to a linear regression analysis considering as dependent variables, separately, the number of curricular units approved (1st semester) and the average of the classifications on approved units (1st year). Students were previously informed about the research objectives and gave their written consent to participate in the study, Data has been analyzed using the IBM SPSS package (version 24.0)

\section{RESULTS}

Table 1 describes the descriptive statistics for three indicators of academic achievement: mean of access (GPAAccess), number of curricular unities approved at the end of the 1st semester (NCA_1stS) and the mean of the marks that students obtained on curricular units approved at the end of the 1st year (MCUA_1stY). This presentation considers students separated by gender.

TABLE 1. ACADEMIC ACHIEVEMENT BY GENDER

\begin{tabular}{|l|l|l|l|l|l|}
\hline Variables & Gen & Min & Max & Mean & SD \\
\hline GPA_Access & M & 107 & 200 & 152.46 & 17.99 \\
\hline & F & 115 & 193 & 158.98 & 17.32 \\
\hline NCA_1rstS & M & 10 & 12 & 11.05 & .99 \\
\hline & F & 10 & 12 & 11.31 & .94 \\
\hline MCUA_1rstY & M & 10.00 & 18.92 & 13.09 & 1.57 \\
\hline & F & 10.50 & 18.40 & 13.84 & 1.55 \\
\hline
\end{tabular}

Results suggest that female students have a better average academic achievement, although the maximum classifications are obtained by male students (a group where we can find a large variance). Using t-test to compare means by gender, in these three indicators of academic achievement a significant effect in favor of female students was obtained: GPA_Access $(\mathrm{t}$ $=-4.58, \mathrm{p}<.001), \mathrm{NCA} \_1 \mathrm{stS}(\mathrm{t}=-3.253, \mathrm{p}<.01)$ and MCUA_1stY $(\mathrm{t}=-5.529, \mathrm{p}<.001)$.

Table 2 presents the magnitude of the dependent variables effects on the number of curricular units students have made with success, during the first semester (regression analysis with method enter). This model is significant $(\mathrm{F}(7,658)=13.318, \mathrm{p}$ $<.001$ ), but only $8 \%$ of the variance on the number of disciplines passed was explained taking this group of independent variables ( $\mathrm{R}$ squared adjusted).

TABLE 2. REGRESSION ANALYSIS FOR NCA

\begin{tabular}{|l|l|l|l|l|}
\hline \multirow{2}{*}{ Variables } & \multicolumn{4}{|c|}{ Statistical parameters } \\
\cline { 2 - 5 } & \multicolumn{1}{|c|}{$\boldsymbol{B}$} & \multicolumn{1}{|c|}{ Beta } & \multicolumn{1}{c|}{$\boldsymbol{t}$} & \multicolumn{1}{c|}{ Signif } \\
\hline Constant & 2.580 & & 5.321 & .000 \\
\hline Age & -.008 & -.005 & -.143 & .886 \\
\hline Gender & .485 & .182 & 4.821 & .000 \\
\hline GPAAccess & .013 & .179 & 4.157 & .000 \\
\hline Father Schooling & -.064 & -.042 & -.874 & .383 \\
\hline Mother Schooling & -.219 & -.144 & -.2 .998 & .003 \\
\hline $\begin{array}{l}\text { Course (1 } \\
\text { choice) }\end{array}$ & -.006 & -.003 & -.063 & .950 \\
\hline $\begin{array}{l}\text { University (1 } \\
\text { option) }\end{array}$ & -.239 & -.086 & -2.145 & .032 \\
\hline
\end{tabular}


Statistics analysis shows that only $8 \%$ of the variance in the number of curricular units approved by students at the end of the 1st semester was explained by the ensemble of independent variables considered in the regression equation. The number of disciplines approved is particularly associated with gender (female students with a large number or a better achievement) and with the GPA-Access (using the stepwise method the variance explained by gender alone is $5 \%$ ). In both cases, the impact is significant at $\mathrm{p}<.001$. Considering the parents' level of schooling, the impact is significant for mothers $(p<.01)$. In both cases, students with parents with a low level of schooling obtained a large number of disciplines approved at the end of the first semester.

On Table 3 we present the results of regression analysis to predict the mean of classifications students obtain in the approved disciplines (method enter). The model is significant $(\mathrm{F}(7,639)=31.99, \mathrm{p}<.001)$, and $25 \%$ of the variance on classifications was explained (R squared adjusted).

TABLE 3. REGRESSION ANALYSIS FOR MEAN GRADE

\begin{tabular}{|l|c|c|c|c|}
\hline \multirow{2}{*}{ Variables } & \multicolumn{4}{|c|}{ Statistical parameters } \\
\cline { 2 - 5 } & \multicolumn{1}{|c|}{$B$} & Beta & \multicolumn{1}{c|}{ Signif } \\
\hline Constant & 5.883 & & 4.103 & .000 \\
\hline Age & .095 & .049 & 1.413 & .158 \\
\hline Gender & .602 & .174 & 5.040 & .000 \\
\hline GPA_Access & .041 & .451 & 11.420 & .000 \\
\hline Father Schooling & .049 & .025 & .564 & .573 \\
\hline Mother Schooling & -.271 & -.137 & -3.115 & .002 \\
\hline $\begin{array}{l}\text { Course (1 } \\
\text { option) }\end{array}$ & -.252 & -.077 & -2.047 & .041 \\
\hline $\begin{array}{l}\text { University (1 } \\
\text { option) }\end{array}$ & -.409 & -.113 & -3.052 & .002 \\
\hline
\end{tabular}

The results suggest that the GPA-Access assumes particular relevance for explaining Students' classifications in disciplines during the first year at college (with the stepwise method, GPA alone explains $18 \%$ of the variance). Also gender assumes relevance showing that female students obtain better academic classifications. Now the effect of schooling level of mothers is significant (not for fathers) and in favour of the mothers with low academic level of education. Finally, the fact that students are in a course and in an institution they have chosen as their first option when accessing higher education is important (first options are related to better academic achievement).

\section{DISCUSSION AND CONCLUSION}

Several personal and academic variables can impact students' achievement and permanence during the 1st year of higher education [ 2-4]. Our data allow us to conclude that the number of curricular units approved at the end of 1st semester depends on other personal and contextual variables not considered in this study (only $8 \%$ of its variance can be associated with the variables here considered). For sure, variables more related to the transition and adjustment process (first weeks at university) are decisive to explain the number of curricular units approved during the first semester.

Taking the academic success at the end of the 1st year (mean of the classifications of the approved curricular units), the access GPA is the variable that best predicts students' academic success in the 1st year of Engineering courses. This variable and its importance reflect the relevance of students' academic background in mathematics, physics and chemistry for engineering courses. These data deserve attention from the institutions and teachers since some students access their courses without the necessary level of academic competencies, justifying the need for diagnosing and levelling previous background and personal characteristics. This attention can also be justified because several students are not in their first option institution/course, which also impacts their academic adjustment process, since those students, usually, present low academic expectations and engagement too.

The results show that students who are in their first option course and institution present a high mean grade curricular units. First options usually express expectations and career vocational projects that, when not implemented arise feelings of frustration and stress. These negative feelings can explain low investment of students in academic activities, therefore, fewer disciplines approved and lower results in the curricular units. $[1,15]$.

Gender is also related to academic achievement. Although Male students can get higher classification in terms of the mean of classifications and the number of approved curricular units, female students, as a group, perform better. This might be related to studying habits, self-regulation and more efficient learning strategies which female students usually assume as well developed.

Considering parents academic background, the results show that better academic achievement is obtained by students whose parents have low school levels. This result is not in line with the majority of studies, where students from favoured sociocultural groups present better academic achievement [4]. As the majority of students come from families without higher education degrees, the fact that students from families with low socioeconomic status have higher grades might be explained by the willingness of these students, and their families, to increase their social and economic status. This can also be related to the fact that the public university, where this study was implemented, is located in a rural and one of the poorest regions of Portugal. These students usually require public financial support or have to enter the world of work and have a salary to support their studies and therefore have reduced time and availability for their studies and academic life.

\section{ACKNOWLEDGEMENT}

This work is financed by Project UID/CTM/00264/2019 of 2C2T - Centro de Ciência e Tecnologia Têxtil, and by CIEd 
-Research Centre on Education, project UID/CED/01661/2019, Institute of Education, University of Minho, through national funds of FCT/MCTES-PT.

\section{REFERENCES}

[1] A. M Araújo, C. M., Gomes, L. S., Almeida and J. C. Nuñez, “A latent profile analysis of first-year university students' academic expectations", in Anales de Psicologia, vol.35(1), pp.5867. doi:10.6018/analesps.35.1.299351, 2019.

[2] M. L. Upcraft, J. N. Gardner and B. O. Barefoot, (Eds), "Challenging and supporting the first-year student: A handbook for improving the first year of college", San Francisco, CA: Jossey-Bass, 2005.

[3] M. F. P. Fernández, A. M. Araújo, C. T. Vacas, L. S. Almeida and M. S. R. Gonzalez, "Predictors of students' adjustment during the transition to university in Spain", Psicothema, vol. 29(1), pp.67-72. , 2017.

[4] E. T. Pascarella and P.T. Terenzini, "How college affects students", Volume 2: A third decade of research. San Francisco: Jossey-Bass 2005.

[5] J. R. Casanova, A. Cervero, J. C. Nuñez, L. S. Almeida and A. Bernardo, "Factors that determine the persistence and dropout of university students" Psicothema, vol. 30(4), pp.408-414. doi:10.7334/psicothema, 2018.

[6] R. D. Padgett, "The effects of the first year of college on undergraduates' development of altruistic and socially responsible behavior", University of Iowa Research Online. http://ir.uiowa.edu/cgi/viewcontent.cgi?article=2437\&context=etd, 2011.

[7] R. D. Padgett and J. R. Keup,"2009 National Survey of First-Year Seminars: Ongoing Efforts to Support Students in Transition", in Research Reports on College Transitions No. 2. National Resource Center for The First-Year Experience and Students in Transition. University of South Carolina, 1728 College Street, Columbia, SC 29208, 2011

[8] R. L. Swing, "The impact of engaging pedagogy on first-year seminars", Policy Center on the First year of College Report. http://www.sc.edu/fye/resources/assessment/essays/swing8.28.02 pdfs/introduction.pdf, 2002.

[9] J. B. Cuseo, "The empirical case for the first-year seminar": Course impact on student retention and academic achievement. E-Source for College Student Transitions, vol. 6(6), pp.5-7, 2009.
[10] C. D. Ryff and B. H. Singer, "Know thyself and become what you are: A eudaimonic approach to psychological well-being", Journal of Happiness Studies, Vol. 9, Issue 1, pp. 13-39, January 2008.

[11] N. A. Bowman, "The development of psychological well-being among first-year college students" Journal of College Student Development, vol.51(2), 180-200, 2010.

[12] E. T. Pascarella, "The impact of first-year seminars on college students' life-long learning orientations" Journal of Student Affairs Research and Practice, vol. 50(2), pp. 133-151, 2013.

[13] A. M. Diniz et al., "Gender differences in first-year college students' academic expectations. Studies in Higher Education”, pp.1-13. doi:10.1080/03075079.2016.1196350, 2018.

[14] M. Fonseca, D. Dias, C. Sá and A.Amaral, "Waves of (dis)satisfaction: effects of numerus clausus system in Portugal" European Journal of Education, Doi 10.1111/ejed.12042, in The Exploration of Happiness 2008 pp. 97-116, Springer Netherlands, 2014.

[15] M. E. Ferrão and L. S. Almeida, "Multilevel modeling of persistence in Higher Education", Ensaio: aval. pol. públ. Educ., Rio de Janeiro, vol. 26(100), pp. 664-683. doi: 10.1590/S0104$40362018002601610,2018$.

[16] M.Richardson, Ch.Abraham and R.Bond, "Psychological Correlates of University Students' Academic Performance: A Systematic Review and Meta-Analysis", Psychological Bulletin, vol. 138(2), pp.353-387. doi: 10.1037/a0026838, 2012.

[17] S.B.Robbins, K. Lauver, H. Le, D. Davis, R. Langley, and A. Carlstrom, "Do psychosocial and study skill factors predict college outcomes? A meta-analysis" Psychological Bulletin,vol. 130,pp. 261-288. doi: 10.1037/0033-2909.130.2.261, 2004.

[18] K.V.T. Bui, "First-generation college students at a four-year university: Background characteristics, reasons for pursuing higher education, and first-year experiences", College Student Journal, 36(1), 3-12, 2002)

[19] M.M.Lohfink, \& M.B Paulsen, "Comparing the determinants of persistence for first-generation and continuing-generation students", Journal of College Student Development,vol. 46(4), pp.409-428, 2005.

[20] S.S.Mehta, J.J.Newbold and M.A.O'Rourke, "Why do firstgeneration students fail?", College Student Journal, vol. 45(1), pp.20-35, 2011.

Curricular units 